\title{
“OLHEM PARA MIM. EU NÃO NASCI ASSIM": A COLABORAÇÃO DO DESIGN SOCIAL NA INCLUSÃO DE CRIANÇAS ESCALPELADAS
}

Michele Silva e Silva

Universidade do Estado do Pará

michele.kairos@gmail.com

Antonio Victor lima Ferreira

Universidade do Estado do Pará

avictorlf0106@outlook.com

Rodrigo Augusto de Sousa Cavalcante

Universidade do Estado do Pará

rodrigo_171192@hotmail.com

Thiago Guimarães Azevedo

Universidade do Estado do Pará

azevedo_thiago@yahoo.com.br

Resumo: O Brasil é conhecido por sua grande rede fluvial e tendo como a região amazônica como a maior bacia hidrográfica do mundo. Deste modo as embarcações mostram-se indispensáveis no cotidiano da população que mora ao longo das margens dos rios. Nas cidades ribeirinhas, não se costuma ter ensinamento formal sobre a arte ou ofício de pilotar barcos e canoas, pois esse é um aprendizado que passa de pai para filhos. É relevante ressaltar que por morar longe da capital, e pelas poucas escolas nas ilhas, a escolaridade do ribeirinho é rudimentar, predominando o semianalfabetíssimo ou o analfabetismo, entretanto, percebe-se a exuberância de conhecimento empírico no seu modo de vida. E com a chegada dos motores a combustão na Amazônia em 1970, é com muita frequência que se têm registros de acidentes nos quais mulheres e principalmente crianças, perdem parte ou completamente o couro cabeludo, às vezes orelhas, pele do pescoço e do rosto e algumas delas chegam ao óbito. $O$ acidente tem graves repercussões, tanto pelo mecanismo de lesão, quanto pelas consequências psicológicas e sociais significativas, pois afeta a autoestima, identidade, percepção corporal, o humor, à sociabilidade, causam danos neurológicos, como perda de visão e audição que podem ser irreversíveis e contribui para alterar a dinâmica e a economia familiar, o escalpelamento também esta associada à alta taxa de mortalidade infantil. De frente aos inúmeros acidentes de escalpelamento que impõe sequelas físicas e causa um imenso sofrimento durante todo o tratamento e no decorrer da vida dos pacientes. Como o design pode colaborar nos traumas sociais vivenciados por crianças, que são as que mais sofrem de escalpelamento decorrente do eixo de motores de 
pequenas embarcações nas regiões ribeirinhas, na cidade de Belém no estado do Pará? . Contudo a pesquisa etnográfica se mostra relevante no mundo do design social e de produto, no sentido de aprofundar os aspectos relacionados à busca de soluções mais centrados no problema e na identificação de alternativa que envolve a relação das vitimas com a sociedade. É relevante refletir o que o design de produto pode oferecer as vitimas que sofrem preconceito e não aceitação de si mesmo, e como este pode ajudar a facilitar a interação social delas criando condições para uma vida aceita e mais feliz através de um produto.

Palavras-chave: Escalpelamento, Design Social, Produto 